УДК 657.471.12:331.214.72

JEL Classification: M12

O. К. СЛICССBA,

доктор економічних наук, професор, зав. кафедри статистики, обліку та економічної інформатики,

Дніпровський ноціональний університет імені Олесл Гончара Н. Г. КУТОВА, стариий викладач кафедри економіки, організачії та управління підприсмствами, ДВНЗ "Криворізький ноціональний університет"

\title{
Система оцінювання ефективності стимулювання персоналу на основі інтегрального показника
}

За допомогою корелячійно-регресійного аналізу визначено інтегральний показник ефективності стимулювання персоналу підприємства та чинники впливу на засоби його стимулювання. Складено матрицю коригувальних заходів зі стимулювання персоналу на досліджуваних підприсмствах, за допомогою якой визначено діапазон значень розрахованого інтегрального показника ефективності стимулювання персоналу. Визначено стан механізму стимулювання персоналу на досліджуваних підприсмствах на підставі розрахунку інтегрального показника ефективності стимулювання персоналу nidприємств

Ключові слова: механізм стимулювання, засоби стимулювання, інтегральний показник ефективності стимулювання персоналу, підприємство.

Постановка проблеми. Одним із головних чинників ефективності підприємства у нестабільних кризових умовах $€$ його здатність до своєчасного та конструктивного реагування на зміни, що загрожують його нормальному функціонуванню, з переналагодженням внутрішнього економічного механізму. Найкращих кінцевих результатів в умовах кризи досягають ті підприємства, які в процесі діяльності спромоглися побудувати ефективний механізм стимулювання персоналу.

В економічній науці проблеми стимулювання працівників є одними з найбільш помітних. Вони мають важливе теоретичне та практичне значення, оскільки вони пов'язані з ефективним використанням ключового фактора виробництва - персоналу підприємства. Підвищення ефективності функціонування підприємств вимагає удосконалення механізму стимулювання персоналу, що покращить показники якості роботи та дозволить підприємствам конкурувати на світових ринках. Це обумовлює актуальність проблеми дослідження.

Аналіз літературних джерел. Питання стимулювання персоналу досліджуються в економічній літературі вже досить давно. Основи теоретичного осмислення цієї проблеми було закладено ще в XVIII столітті А. Смітом та Д. Рікардо. А. Маслоу, Ф. Герцберг, Д. Мак-Клелланд, Л. Портер, Е. Лоулер, Е. Мейо та інші розробили загальні принципи теорії мотивації, поведінки людини в досягненні результатів праці і на цій основі пропонували різні механізми винагороди працівників за досягнення поставлених виробничих цілей. Окремі аспекти проблеми стимулювання персоналу висвітлено в працях вітчизняних і закордонних авторів: В. Карліна, А. Колота, В. Кучера, В. Беліка, Н. Чорноморченко Т. Гільорме, І. Поварич, Б. Прошкіна, Г. Попова, Л. Бляхмана, Ф. Щербака, Ф. Герцберга, О. Макгрегова, О. Єлісеєвої та інших.

Актуальність цієї проблеми та недостатнє її вивчення в аспекті окремих галузей визначили вибір теми дослідження, обумовили його мету і завдання.

Метою статті є розроблення системи оцінювання ефективності стимулювання персоналу та ії апробація на підприємствах.

Виклад основного матеріалу. Аналіз праць [1;2;3] виявив такі проблеми, пов'язані зі стимулюванням роботи персоналу на підприємствах: відсутність дієвого

(C) О. К. Слісєєва, Н. Г. Кутова, 2017 
механізму стимулювання персоналу; недостатнє проведення моніторингу якості робочої сили; відсутність ефективних інструментів раціонального управління робочим часом персоналу та планування кар'єри; неоптимальна структура соціального пакету (проблеми із забезпеченням житлом, відсутність недержавного пенсійного страхування тощо); низька ефективність системи безпеки праці; рівень заробітної плати, що не відповідає очікуванням працівників; низький рівень інвестування в розвиток персоналу; недосконалість системи мотиваційного забезпечення та ін.

Отже, відсутність дієвого механізму стимулювання персоналу на підприємствах $€$ однією 3 найважливіших проблем управління персоналом, що обумовлює необхідність розроблення заходів з його удосконалення.

Формування механізму стимулювання персоналу підприємств авторами запропоновано здійснювати на основі функціонального підходу, при якому стимулювання $\epsilon$ ключовою функцією управління персоналом.

При моделюванні засобів стимулювання персоналу використовувались такі показники:

- засоби матеріального стимулювання; показники: витрати заробітної плати 3 нарахуваннями на гривню обсягу продукції; річний виробіток на одного працюючого; витрати заробітної плати на гривню реалізованої продукції; зростання частки премій, доплат і надбавок у загальному фонді оплати праці (ФОП); зростання основної та додаткової оплати, заохочень і компенсаційних виплат у ФОП; зростання фонду соціального розвитку; відношення суми преміальних виплат за подані ідеї, раціоналізаторські пропозиції, нові рішення до загальної суми преміальних виплат на підприємстві; індекс середньої заробітної плати;

- засоби організаційного стимулювання; показники: професійно-кваліфікаційний рівень персоналу; підвищення рівня охоплення робіт нормами й нормативами; кількість працівників, які працюють в умовах, що не відповідають санітарно-гігієнічним нормам; рівень професійних захворювань та травматизму; відношення середньої заробітної плати персоналу, шо займається інноваціями на підприємстві, до загальної суми ФОП; відношення витрат на навчання новим професіям та підвищення кваліфікації до загальних витрат на персонал; рівень комунікації всередині підприємства; коефіцієнт підвищення кваліфікації персоналу; коефіцієнт втрат робочого часу; коефіцієнт плинності кадрів;

- засоби соціально-психологічного стимулювання; показники: виплати із соціального захисту на одного працівника; відсоток персоналу з кадрового резерву підприємства, призначеного на цільову посаду; співвідношення між кількістю подяк та кількістю доган персоналу за звітний період; співвідношення між кількістю подяк на загальних зборах, у 3МI, на персональному сайті компанії, на корпоративній дошці пошани та кількістю особистих подяк персоналу за звітний період; обсяг інвестицій у медичне обслугову вання і соціальне страхування; ступінь підвищення привабливості робочого місця; коефіцієнт управлінсыкого навантаження.

Для визначення індикаторів засобів стимулювання персоналу, які є базою для розрахунку інтегрального показника ефективності стимулювання персоналу підприємства, проведено аналіз вказаних вище показників.

На основі конщепції функціонального підходу інтегральний показник ефективності стимулювання персоналу розраховується на базі індикаторів засобів стимулювання персоналу.

Показник ефективності управління персоналом являє собою кількісне вираження певної характеристики індикатора ефективності управління персоналом, яке надає змогу оцінювати прогрес, підвишувати ефективність і дієвість прийняття рішень.

Інформаційною базою для дослідження $є$ дані фінансової та нефінансової звітності підприємств, статистичних агенцій, Державної служби статистики України [4], статистичні збірники комітетів та департаментів державної влади [5], Міністерства економіки України тощо. 
Процес моделювання має певні обмеження, які пов'язані з необхідністю формування параметрів, уточнення вагових коефіцієнтів, проведення попередніх розрахунків, аналізу проміжних і кінцевого результатів [6]. Також допустимі щорічне оновлення значень індикаторів за річними даними звітності підприємств та служби статистики, можливість аналізувати зміну значень у динаміці [7;8].

Інтегральний показник ефективності стимулювання персоналу підприємств $I_{\text {stimul }}$ вказує на рівень ефективності управління персоналом; авторами рекомендовано визначати його як сумарну величину часткових статичних індикаторів за формулою:

$$
I_{\text {stimul }}=\sum_{i=1}^{3} \beta_{i} \times I_{b p_{i}},
$$

де $\beta_{i}$ - коефіцієнт впливу відповідних індикаторів на інтегральний індикатор ефективного стимулювання персоналу відповідного засобу стимулювання; $I_{b p_{i}}$ індикатор засобу стимулювання персоналу; $i$ - кількість засобів стимулювання персоналу.

Межі вимірювання інтегрального показника ефективності управління персоналом $I_{\text {stimul }}$ знаходяться в діапазоні $[0 ; 1]$.

Наведемо приклад розрахунку індикатора соціально-психологічного стимулювання персоналу $\left(I_{\text {soo }}\right)$ за запропонованою методикою:

Індикатору соціально-психологічного стимулювання персоналу $I_{s o c}$ відповідають показники $s l-s 7$ :

$s I-$ виплати із соціального захисту на одного працівника, тис. грн;

$s l:=\left(\begin{array}{llll}0.6 & 0.920 .51 & 0.54 & 0.65\end{array}\right)^{T}-$ нормування;

$s 2$ - відсоток персоналу з кадрового резерву підприємства, призначеного на цільову посаду;

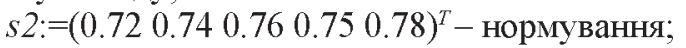

$s 3$ - співвідношення між кількістю подяк та доган персоналу за звітний період;

$s 3:=(0.820 .840 .860 .830 .85)^{T}-$ нормування;

$s 4$ - співвідношення між кількістю подяк на загальних зборах, у ЗМІ, на персональному сайті компанії, на корпоративній дошці пошани та кількістю особистих подяк персоналу за звітний період;

$s 4:=\left(\begin{array}{lll}0.94 & 0.920 .95 & 0.910 .90\end{array}\right)^{T}-$ нормування;

$s 5$ - ступінь інвестування в медичне обслуговування і соціальне страхування, частка витрат на медичне обслуговування і соціальне страхування в сукупних соціальних витратах підприємства;

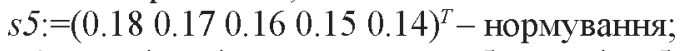

$s 6$ - ступінь підвищення привабливості робочого місця (підприємства взагалі);

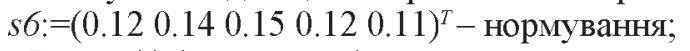

$s 7$ - коефіцієнт управлінського навантаження;

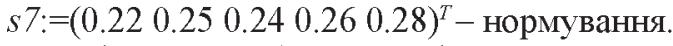

Перевірка даних $(s 1-s 7)$ здійснюється за парною кореляцією для встановлення функціональних зв'язків між показниками індикатора мотивації на досліджуваних підприємствах (рис. 1).

$$
s 1:=\left(\begin{array}{l}
\operatorname{corr}(s 1, s 1) \operatorname{corr}(s 1, s 2) \operatorname{corr}(s 1, s 3) \operatorname{corr}(s 1, s 4) \operatorname{corr}(s 1, s 5) \operatorname{corr}(s 1, s 6) \operatorname{corr}(s 1,7) \\
\operatorname{corr}(s 2, s 1) \operatorname{corr}(s 2, s 2) \operatorname{corr}(s 2, s 3), \operatorname{corr}(s 2, s 4) \operatorname{corr}(s 2, s 5) \operatorname{corr}(s 2, s 6) \operatorname{corr}(s 2, s 7) \\
\operatorname{corr}(s 4, s 1) \operatorname{corr}(s 4, s 2) \operatorname{corr}(s 3, s 3) \operatorname{corr}(s 3, s 4) \operatorname{corr}(s 3, s 5) \operatorname{corr}(s 3, s 24) \operatorname{corr}(s 3, s 7) \\
\operatorname{corr}(s 5, s 1) \operatorname{corr}(s 5, s 2) \operatorname{corr}(s 5, s 3) \operatorname{corr}(s 5, s 4) \operatorname{corr}(s 5, s 5) \operatorname{corr}(s 5, s 6) \operatorname{corr}(s 5, s 7) \\
\operatorname{corr}(s 6, s 1) \operatorname{corr}(s 6, s 2) \operatorname{corr}(s 6, s 3) \operatorname{corr}(s 6, s 4) \operatorname{corr}(s 6, s 5) \operatorname{corr}(s 6, s 6) \operatorname{corr}(s 6, s 7) \\
\operatorname{corr}(s 7, s 1) \operatorname{corr}(s 7, s 2) \operatorname{corr}(s 7, s 3) \operatorname{corr}(s 7, s 4) \operatorname{corr}(s 7, s 5) \operatorname{corr}(s 6, s 6) \operatorname{corr}(s 7, s 7)
\end{array}\right)
$$




$$
s 1=\left(\begin{array}{cccccccc}
1 & -0.178 & -0.068 & -0.293 & 0.271 & 0.134 & 0.123 \\
-0.178 & 1 & 0.778 & -0.485 & -0.919 & -0.136 & 0.85 \\
-0.068 & 0.778 & 1 & 0.076 & -0.5 & 0.481 & 0.424 \\
-0.293 & -0.485 & 0.076 & 1 & 0.686 & 0.69 & -0.863 \\
0.271 & -0.919 & -0.5 & 0.686 & 1 & 0.385 & -0.919 \\
0.134 & -0.136 & 0.481 & 0.69 & 0.385 & 1 & -0.408 \\
0.123 & 0.85 & 0.424 & -0.863 & -0.919 & -0.408 & 1
\end{array}\right)
$$

Рис. 1. Числові матриці "s 1 - виплати із соціального захисту на одного працівника" на прикладі ПАТ "КЗРК"

Джерело: сформовано автором

Отримані результати є необхідною підставою для проведення подальшого моделювання впливу окремих показників на ефективність стимулювання персоналу підприємства. Використовуючи метод множинної регресії, можна визначити, які змінні мають найбільший вплив на засоби стимулювання персоналу підприємства.

На підставі розрахунку інтегрального показника ефективності стимулювання персоналу підприємств та сформованої шкали оцінювання рівня ефективності стимулювання персоналу визначено стан механізму стимулювання персоналу.

У результаті проведення розрахунків установлено, що на ефективність стимулювання персоналу досліджуваних підприємств впливають показники окремих засобів стимулювання.

3 урахуванням вишевикладених результатів зазначимо, шо найважливішим чинником кількісного характеру, що впливає на забезпечення високої ефективності стимулювання персоналу, є матеріальне стимулювання.

У табл. 1 представлено значення інтегрального показника ефективності стимулювання персоналу для трьох досліджуваних підприємств за 2011-2015 pр.

Табличя 1

Значення інтегрального показника ефективності стимулювання персоналу для досліджуваних підприємств за 2011-2015 рр.

\begin{tabular}{|l|c|c|c|c|c|}
\hline \multirow{2}{*}{\multicolumn{1}{|c|}{ Підприсмство }} & \multicolumn{5}{|c|}{ Роки } \\
\cline { 2 - 6 } & $\mathbf{2 0 1 1}$ & $\mathbf{2 0 1 2}$ & $\mathbf{2 0 1 3}$ & $\mathbf{2 0 1 4}$ & $\mathbf{2 0 1 5}$ \\
\hline ПАТ "КЦР3" & 0,37 & 0,35 & 0,33 & 0,32 & 0,3 \\
\hline ПАТ "КЗРК" & 0,61 & 0,58 & 0,56 & 0,51 & 0,52 \\
\hline ПАТ "КЗГО" & 0,43 & 0,46 & 0,44 & 0,46 & 0,45 \\
\hline
\end{tabular}

Джерело: сформовано автором на основі власних досліджень

Необхідно зазначити, що жодне з трьох досліджуваних підприємств не увійшло у групу з високим рівнем інтегрального показника ефективності стимулювання персоналу, шо свідчить про необхідність коригування механізму стимулювання персоналу на всіх цих підприємствах.

До першої групи входить ПАТ “КЗРК”' (середнє значення $I_{\text {stimul }}=0,556$ ), яке має найвищий рівень стимулювання персоналу, що супроводжується значною часткою витрат на засоби матеріального стимулювання для підвищення рівня продуктивності праці персоналу.

До другої групи із середнім рівнем ефективності стимулювання персоналу входить ПАТ "КЗРК” (рис. 2), що супроводжуеться стабільним станом, наявними можливостями для подальшого ефективного розвитку. Але у зв' язку з поступовим зменшенням інтегрального показника ефективності стимулювання персоналу за 2011-2015 pp. (зменшення на $14,75 \%$ у 2015 р. порівняно з 2011 р.) ПАТ "КЗРК" потребує розроблення нових заходів стимулювання персоналу, пов язаних із корегуванням засобів 
матеріального стимулювання. Це підприємство зосереджувалось на матеріальному стимулюванні прямого впливу, але після побудови карт мотиваторів і демотиваторів та їх аналізу можливо запропонувати заходи непрямого матеріального стимулювання (формування системи недержавного пенсійного страхування).

До третьої групи з низьким рівнем інтегрального показника ефективності стимулювання персоналу входять ПАТ “КЦРЗ" (середнє значення $I_{\text {stimut }}=0,316$ ) та ПАТ “КЗГО" (середне значення $I_{\text {stimul }}=0,444$ ), шо значною мірою обумовлено нестабільним станом цих підприємств, який не відповідає умовам забезпечення відповідного рівня ефективності діяльності персоналу. Найнижчий рівень спостерігається на ПАТ “КЦРЗ" (середнє значення $I_{\text {stigul }}=0,316$ ). Таке значення показника обумовлено низыким рівнем продуктивності праці, неналагодженою системою інформаційного та мотиваційного забезпечення ефективності стимулювання персоналу.

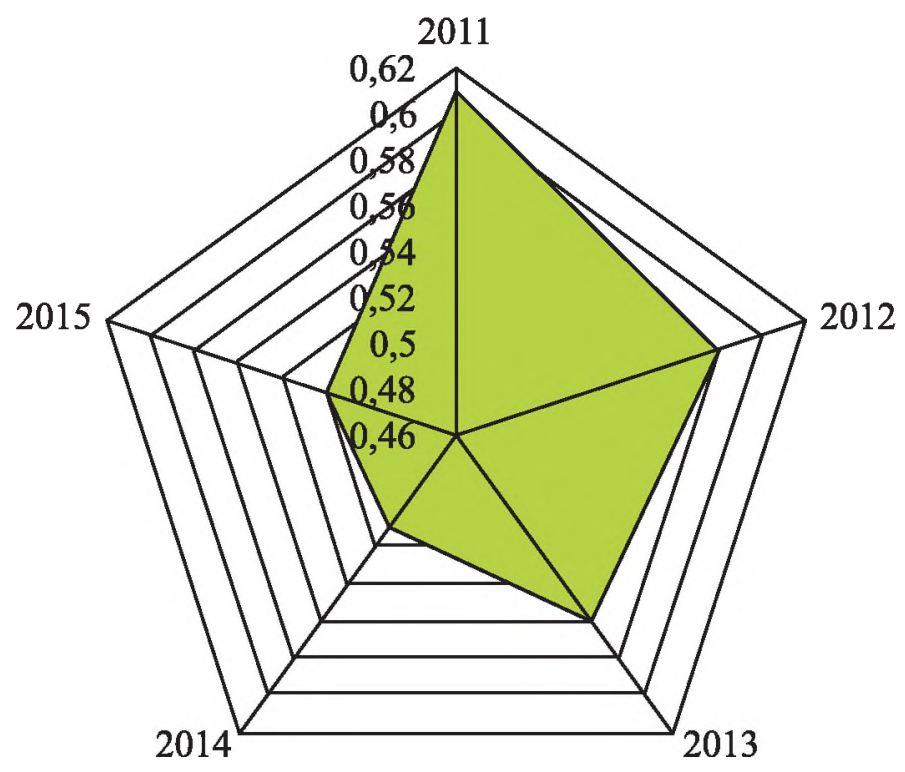

Рис. 2. Графічна інтерпретація динаміки інтегрального показника стимулювання персоналу (на прикладі ПАТ "КЗРК”)

Джерело: сформовано автором на основі власних досліджень

У табл. 2 представлено матрицю заходів щодо корегування інтегрального показника ефективності стимулювання персоналу для досліджуваних підприємств.

Таблиия 2

Матриця коригувальних заходів зі стимулювання

на досліджуваних підприсмствах

\begin{tabular}{|c|c|c|c|}
\hline Рівні & Підприємства & $\begin{array}{c}\text { Діапазон значень } \\
\text { розрахованого } \\
\text { інтегрального } \\
\text { показника } \\
\text { ефективності } \\
\text { стимуювання } \\
\text { персоналу }\left(I_{\text {stimut }}\right)\end{array}$ & Заходи \\
\hline 1 & 2 & 3 & 4 \\
\hline Високий & $\mathrm{X}$ & $\mathrm{X}$ & $\mathrm{X}$ \\
\hline Середній & ПАТ "КЗРК” & {$[0,51-0,61]$} & $\begin{array}{l}\text { розроблення коригувальних заходів } \\
\text { матеріального стимулювання непря- } \\
\text { мого впливу задля уникнення погір- } \\
\text { шення ситуації на підпичмстві }\end{array}$ \\
\hline
\end{tabular}




\begin{tabular}{|c|c|c|c|}
\hline 1 & & 3 & \\
\hline \multirow[t]{2}{*}{ Низький } & ПАТ “КЗГО” & {$[0,43-0,46]$} & $\begin{array}{l}\text { розроблення нормативної та мето- } \\
\text { дичної кадрової документації; } \\
\text { упровадження методики ділової } \\
\text { оцінки та атестації кадрів для пра- } \\
\text { цівників }\end{array}$ \\
\hline & ПАТ “КЦРЗ" & {$[0,3-0,34]$} & $\begin{array}{l}\text { упровадження заходів, спрямо- } \\
\text { ваних на встановлення чіткого } \\
\text { взаємозв'язку між винагородою та } \\
\text { результатами праці; } \\
\text { упровадження технології управлін- } \\
\text { ня профорієнтацією та адаптацією } \\
\text { (можливе створення системи на- } \\
\text { ставництва) }\end{array}$ \\
\hline $\begin{array}{c}\text { Слабкий } \\
\text { (обмежений) }\end{array}$ & {$[0-0,29]$} & $X$ & $\mathrm{X}$ \\
\hline
\end{tabular}

Джерело: сформовано автором на основі власних досліджень

Доцільно розглянути заходи для збільшення інтегрального показника ефективності стимулювання персоналу для кожного підприємства окремо, для яких було побудовано аналогічні графічні інтерпретації динаміки цього показника.

Хоча ПАТ “КЗГО” має стабільно середній рівень інтегрального показника ефективності стимулювання персоналу, але збиток від діяльності у 2015 році свідчить про необхідність застосування коригувальних дій, а саме: розроблення нормативної та методичної кадрової документації (оскільки наявна документація не відповідає сучасному науково обгрунтованому організаційно-методичному забезпеченню управління персоналом), упровадження методики ділової оцінки та атестації кадрів для працівників.

ПАТ “КЦРЗ" має не тільки найнижче значення інтегрального показника ефективності стимулювання персоналу (мінімальне - 0,3 у 2015 p., максимальне $-0,37$ у 2011 р.). Проведений аналіз показує, що незважаючи на необхідність коригувальних заходів механізму стимулювання з метою запобігання переходу на слабкий (обмежений) рівень (у 2015 р. значення інтегрального показника склало 0,3 (гранична межа)), у ПАТ "КЦРЗ" відсутні насамперед фінансові можливості для запровадження змін у механізмі. Тому, на наш погляд, необхідно вживати заходів, які не є витратними, наприклад, таких, що спрямовані на встановлення чіткого взаємозв язку між винагородою та результатами праці. Таким заходом з матеріального стимулювання є перегляд оцінки кваліфікації персоналу на основі розрахунку рівня соціально-професійної якості, упровадження технології управління профорієнтацією та адаптацією (можливе створення системи наставництва).

Таким чином, використання інтегрального показника стимулювання персоналу дає змогу об’ єктивно оцінити заходи зі стимулювання персоналу за допомогою запропонованої системи оцінювання ефективності стимулювання. При використанні трендового аналізу можна спрогнозувати значення інтегрального показника стимулювання персоналу для кожного досліджуваного підприсмства за певний період та скорегувати заходи зі стимулювання персоналу.

Висновки. Проведені розрахунки свідчать, що використання інтегрального показника стимулювання персоналу дає змогу об'єктивно оцінити заходи зі стимулювання персоналу підприємства за допомогою запропонованої системи оцінювання ефективності стимулювання, а побудова матриці коригувальних заходів зі стимулювання персоналу сприятиме прийняттю більш оперативних і оптимальних рішень в цій важливій для підприємства сфері. 


\section{Список використаних джерел}

1. Акімова О. А. та ін. Аналіз сталого розвитку - глобальний і регіональний контексти: моногр. Ч. 2. Україна в індикаторах сталого розвитку (2013). К.: НТУУ 'КПІ', 2014. $172 \mathrm{c.}$

2. Маркова Н. С. Формування організаційно-економічного механізму управління розвитком персоналу // Бізнес Інформ. 2012. № 6. С. 200-202.

3. Эккерсон У. Панели индикаторов как инструмент управления: ключевые показатели эффективности, мониторинг деятельности, оценка результатов. М.: Альпина Бизнес Букс, 2007. $400 \mathrm{c}$.

4. Статистична інформація - Офіційний сайт Державної служби статистики України [Електронний ресурc]. URL: URL: http://ukrstat.gov.ua.

5. Бізнес новини в Україні: розвиток інтернет-торгівлі [Електроний ресурс]. 2014. № 5. URL: http://www.finbrok.in.ua/biznes/novosti/3587-v-ukraine-stremitelno-razvivaetsyainternet-torgovlya

6. Гільорме Т. В., Єлісєєва О. К. Моделі управління персоналом підприємства: методологічна платформа та шляхи застосування: моногр. Дніпропетровськ: “ФОП Дробязко С. I.", 2016. 170 с.

7. Єлісєєва О. К., Лижник Ю. Б. Статистичний аналіз та моделювання соціальноекономічних процесів. Дніпропетровськ: “Наука і освіта", 2012. 216 с.

8. Слісєєва О. К., Ситало Є. Застосування інтегрального показника для порівняльної оцінки розвитку регіонів України // Прикладна статистика: проблеми теорії та практики: зб. наук. пр. Вип. 10. К.: ДП “Тнформ.-аналіт. агенство”, 2013. С. 128-135.

O. К. ЕЛИСЕЕВА, доктор экономических наук, профессор, зав. кафедрой статистики, учета и экономической информатики,

Днепровский национальныий университет имени Олеся Гончара Н. Г. КУТОВАЯ,

стариий преподаватель кафедры экономики, организации и управления предприятиями, ГВУЗ «Криворожский наңиональныий университет»

\section{Система оценивания эффективности стимулирования персонала на основе интегрального показателя}

С помощью корреляциионо-регрессионного анализа определен интегральный показатель эффективности стимулирования персонала предприятия и факторы влияния на средства его стимулирования. Составлена матрица корректирующих мероприятий по стимулированию на исследуемых предприятиях, с помоцью которой определен диапазон значений рассчитанного интегрального показателя эффективности стимулирования персонала. Определено состояние механизма стимулирования персонала на исследуемых предприятиях на основани расчета интегрального показателя эффективности стимулирования персонала предприятий.

Ключевые слова: механизм стимулирования, средства стимулирования, интегральный показатель эффективности стимулирования персонала, предприятие. 
O. K. YELISYEYEVA,

Dsc (Economics), Professor, Head of Department for Statistics, Accounting and Economic Informatics, Oles Honchar Dnipro National University

N. H. KUTOVA,

Senior Lecturer of Department for Business Economics, Organization and Management, Kryvyi Rih National University

\section{The System for Assessment of the Effectiveness of Personnel Stimulation on the Basis of Integral Index}

The article's objective is to construct the system for assessment of personnel management performance and its testing on a sample of Ukrainian companies. Problems of personnel stimulation at company level are highlighted. It is proposed to build the mechanism for company personnel stimulation by functional approach. Indicators to be used for assessing the means of personnel stimulation (material stimulation, organizational stimulation, social and psychological stimulation) and personnel management modeling are given. The algorithm for estimating the integral index of the personnel stimulation effectiveness is recommended. Estimation of the index of social and psychological stimulation of company personnel by the proposed method is illustrated. By use of the proposed algorithm it is demonstrated that the material stimulation (salary rate) is the most important determinant of the highly effective personnel stimulation. The integral index of the personnel stimulation effectiveness is estimated by correlation and regression analysis for a sample of Ukrainian companies over 2011-2015. On its basis, the companies under study are grouped by level of personnel stimulation. Corrective measures to increase the integral index of the personnel stimulation effectiveness in each company under study are proposed. The matrix of corrective measures on personnel stimulation at these companies is constructed and used to find the range of estimates of the integral index of the personnel stimulation effectiveness. The quality of personnel stimulation mechanism at company level is assessed on the basis of the estimated integral index of the personnel stimulation effectiveness.

Keywords: stimulation mechanism, means of stimulation, integral index of the personnel stimulation effectiveness, company.

Посилання на статтю:

Слісеєва О. К., Кутова Н. Г. Система оцінювання ефективності стимулювання персоналу на основі інтегрального показника // Науковий вісник Національної академії статистики, обліку та аудиту: зб. наук. праць. 2017. №1-2. С. 46-53. 